\title{
The cigarette pack as image: new evidence from tobacco industry documents
}

\author{
M Wakefield, C Morley, J K Horan, K M Cummings
}

Tobacco Control 2002; 11 (Suppl I):i73-i80

See end of article for authors' affiliations

....................

Correspondence to: Melanie Wakefield, PhD Centre for Behavioural Research in Cancer, Cancer Control Research Institute, Anti-Cancer Council of Victoria, 100 Drummond Street, Carlton, Victoria 3053, Australia; Melanie.Wakefield@

accv.org.au

\begin{abstract}
Objectives: To gain an understanding of the role of pack design in tobacco marketing.
Methods: A search of tobacco company document sites using a list of specified search terms was undertaken during November 2000 to July 2001.

Results: Documents show that, especially in the context of tighter restrictions on conventional avenues for tobacco marketing, tobacco companies view cigarette packaging as an integral component of marketing strategy and a vehicle for (a) creating significant in-store presence at the point of purchase, and (b) communicating brand image. Market testing results indicate that such imagery is so strong as to influence smoker's taste ratings of the same cigarettes when packaged differently. Documents also reveal the careful balancing act that companies have employed in using pack design and colour to communicate the impression of lower tar or milder cigarettes, while preserving perceived taste and "satisfaction". Systematic and extensive research is carried out by tobacco companies to ensure that cigarette packaging appeals to selected target groups, including young adults and women.

Conclusions: Cigarette pack design is an important communication device for cigarette brands and acts as an advertising medium. Many smokers are misled by pack design into thinking that cigarettes may be "safer". There is a need to consider regulation of cigarette packaging.
\end{abstract}

$\mathrm{F}$ or most consumer products, packaging has become an important component of overall marketing strategy. ${ }^{1-3}$ Traditionally, the primary function of a package was to simply contain and protect the product. However, factors such as increased competition and clutter on the retail store shelf have meant that for most products, packaging must perform many sales tasks, such as attracting attention, describing the product, and helping to make the sale. The often cited "four Ps" of marketing-price, promotion, product, and placement-are concepts that summarise the domains of marketing strategy. ${ }^{4}$ As a crucial part of the both the product and promotion, packaging assists consumers to select among other relatively homogenous products.

Cigarette packaging is no exception. In the case of cigarettes, however, packaging is even more critical for several reasons. Firstly, unlike many other products where the packaging is discarded after opening, smokers generally retain the cigarette pack until the cigarettes are used and keep the pack close by or on their person. Thus, cigarette packs are constantly being taken out and opened, as well as being left on public display during use. In this way, cigarette packaging can act as an advertisement. A previous front cover of this journal and accompanying cover essay underlined the importance of cigarette packs as advertisements for cigarettes, especially in the face of advertising restrictions. ${ }^{5}$ This high degree of social visibility leads cigarettes to be known as "badge products". The use of a badge product associates the user with the brand image, giving the user some of the identity and personality of the brand image. One cigarette package designer, John Digianni, states: "A cigarette package is unique because the consumer carries it around with him all day ... it's a part of a smoker's clothing, and when he saunters into a bar and plunks it down, he makes a statement about himself." ${ }^{6}$ When a user displays a badge product, this is witnessed by others, providing a living testimonial endorsement of the user on behalf of that brand and product.

Secondly, cigarette brands enjoy the highest brand loyalty of all consumer products, ${ }^{7}$ with less than $10 \%$ changing brands annually. ${ }^{8}$ Brand choices are usually made early during the life of a smoker, with a high concordance between the brand first smoked and the brand eventually selected as a usual brand. ${ }^{9}$ Thus, once a consumer embraces a cigarette brand, it is quite unlikely that they will change. Tobacco company documents indicate that cigarette companies appreciate the significance of recruiting the young to their own brands. ${ }^{10}$ Brand choice has little to do with the actual cigarette, but with linking the cigarette to aspirations of the smoker or potential smoker. As explained by Thiboudeau and Martin in a recent book on cigarette packaging, cigarette brands "embody the qualities we wish we had, the lives we wish we could lead, the great escapes we wish we could make". ${ }^{11}$ Brand image is the factor that distinguishes between cigarettes and which is important for young smokers in decision making about brand choice. As described by Pollay, this phenomenon essentially makes much of cigarette marketing all about a battle for brand share among the young. ${ }^{10}$ In this context, cigarette packaging can be a critical communication device for creating and reinforcing brand imagery.

Traditionally, advertising is used to establish brand imagery. Packaging reinforces that imagery, by either repeating design elements from advertisements on the package, or displaying features that are consistent with the image advertising. Thus, when a cigarette pack is displayed in a store, it is the sum of its contents, the pack, and its associated imagery, that is purchased by the consumer. However, when there is less opportunity to establish brand imagery through traditional methods of advertising, as is increasingly becoming the case as advertising restrictions come into force, packaging must play a more important role in establishing and driving brand image.

Despite its importance as part of marketing strategy, there has been a relatively small amount of pack related public health research. However, most of the public health gaze on tobacco marketing has focused on tobacco advertising, price, and more recently, product promotions, such as tobacco branded shirts, caps, and other items. For example, a search on PubMed for articles with abstracts from 1990, yielded only 11 English language articles under "smoking $\delta$ product packaging", compared to 298 articles for "smoking \& advertising" and 157 for "smoking $\&$ price". Of research papers on packaging published since 1990, most have focused upon health warnings ${ }^{12-16}$ and generic packaging. ${ }^{17-19}$ Countries who have sought to introduce policies to have warning statements or content information on cigarette packs have found that the 
Table 1 Index of search terms and number of documents returned by tobacco company website

\begin{tabular}{|c|c|c|c|c|c|c|}
\hline Search terms & $\begin{array}{l}\text { Philip } \\
\text { Morris }\end{array}$ & RJ Reynolds & Lorillard & $\begin{array}{l}\text { Brown \& } \\
\text { Williamson }\end{array}$ & $\begin{array}{l}\text { American } \\
\text { Tobacco } \\
\text { Company }\end{array}$ & $\begin{array}{l}\text { British } \\
\text { American } \\
\text { Tobacco }\end{array}$ \\
\hline pack* & 26822 & 20811 & 6412 & 2754 & 2506 & 933 \\
\hline pack* \& research & 5073 & 1583 & 854 & 27 & 127 & 58 \\
\hline pack* \& image* & 52 & 42 & 2 & 2 & - & 48 \\
\hline pack* \& retail & 451 & 385 & 60 & - & 12 & 16 \\
\hline pack* \& innovat* & 92 & 8 & - & - & - & 27 \\
\hline pack* \& market research & 2835 & 31 & 435 & - & - & 2 \\
\hline pack* \& brand plan & 769 & - & 280 & - & - & 5 \\
\hline pack* \& test & 3788 & 1845 & 385 & 235 & 258 & 51 \\
\hline pack * \& point of purchase & 1 & 3 & 1 & 2 & - & - \\
\hline pack * \& point-of-purchase & 1 & 3 & 1 & 11 & - & - \\
\hline pack* \& store & 500 & 233 & 52 & 17 & 32 & 7 \\
\hline pack* \& display & 119 & 326 & 133 & 71 & 28 & 11 \\
\hline pack* \& brand & 4110 & 432 & 979 & 93 & 33 & 97 \\
\hline pack* \& design & 462 & 206 & 51 & 103 & 22 & 95 \\
\hline pack* \& focus group & 74 & 21 & 16 & 9 & - & 3 \\
\hline pack* \& qualitative & 129 & 241 & 16 & 24 & 2 & 5 \\
\hline pack* \& pbrand: Alpine & 308 & & & & & \\
\hline pack* \& pbrand: Marlboro & 3213 & & & & & \\
\hline pack* \& pbrand: Virginia Slims & 2317 & & & & & \\
\hline pack* \& pbrand: Benson \& Hedges & 1307 & & & & & \\
\hline pack* \& pbrand: Camel & & 8012 & & & & \\
\hline pack* \& mbrand: Newport & & & 731 & & & \\
\hline pack* \& mbrand: Winston & & & 22 & & & \\
\hline pack* \& mbrand: Harley Davidson & & & 55 & & & \\
\hline pack* \& mbrand: Lucky Strike & & & & 25 & & \\
\hline
\end{tabular}

tobacco industry vigorously opposes measures that would significantly disrupt brand logos. ${ }^{14} 20$ Without strong tobacco control advocacy, health warnings are often relegated to the side of the pack or cleverly incorporated into the pack design, so as to minimise their intrusiveness and preserve the look of the pack. This kind of response from the industry gives a clear indication that pack design is important.

Aside from the issue of health warnings in disrupting brand image, there is a raft of other packaging issues that warrant research attention to help understand how packaging might influence brand image. For example, what aspects of pack design are most important in communicating or reinforcing brand image? What roles do colour, pack size, and pack construction, for example, play in influencing potential consumers-especially starter smokers, but also other subgroups of consumers - to select one brand over another? What role does packaging play in helping to maintain brand choice against increasing concerns about smoking health risks?

In contrast to the small amount of public health attention on packaging, tobacco companies have conducted a vast amount of consumer research on this subject in their efforts to design packs that might promote cigarette sales. A window on this research has been opened by the public posting of tobacco industry documents made available through lawsuits and under the terms of settlements with the tobacco industry. This paper seeks to better understand, through tobacco industry documents, the role of cigarette pack design in the overall marketing effort used by tobacco companies to promote cigarettes. The paper focuses upon three specific research questions:

- What is the role of cigarette packaging in the total marketing effort for cigarettes and how does this vary when other aspects of the marketing mix are restricted, as in the case of advertising?

- To what extent have tobacco companies used package design to intentionally influence consumer perceptions of product health risks?

- What packaging features most appeal to particular target groups, such as the young, and women?

\section{METHODS}

In order to locate relevant industry documents, the document websites for Philip Morris, RJ Reynolds, Brown \& Williamson, American Tobacco Company, Lorillard Tobacco Company, and British American Tobacco Company (Guildford Depository documents from the Minnesota trial accessed through the Centers for Disease Control and Prevention (CDC) website) as well as the Liggett $\&$ Myers documents, were accessed. A list of search terms was generated with which the term "pack*" could be linked. A full list of search terms, and the resulting number of documents returned on each website, are summarised in table 1. Multiple combinations of these search terms were used, so as to generate a practical number of documents for potential viewing on a particular subject (usually less than 50 documents from each combination of search terms). Searching was terminated when it was clear that no new documents were being returned from different combinations of search terms listed. Searching of the documents was completed in July 2001. All of the documents are available online at http://roswell.tobaccodocuments.org under the "packaging and pricing" collection.

Documents retrieved were dated from the 1950s to the mid 1990s. As table 1 shows, there were thousands of documents about packaging and packaging research. Many documents outlined plans for, and the results of, consumer research on pack design modifications. Some research was qualitative in nature, where a small number of smokers were asked to compare and appraise different packaging configurations, while others were quantitative, reporting data on smoker's responses to questionnaires about aspects of packaging. Some documents were reports and correspondence from consultant companies to the tobacco company, apparently in response to a project brief or request issued by the company. However, it was rare to find briefing correspondence from a tobacco company to one of these consultant firms-only one such document was found from Philip Morris to the Leo Burnett advertising agency in Australia. ${ }^{21}$ A relatively small number of documents were speeches and presentations delivered at company meetings or conferences. Multiple copies of the same 
documents were returned in many search combinations and a minority of illegible documents were found.

\section{RESULTS}

The process of package design and modification is neither rapid nor simple. Typically, the process takes months to several years. In their book on package design, Myers and Lubliner ${ }^{22}$ explain that the process commences with a thorough analysis of the existing product category, which involves gaining an overview of how a range of cigarettes and other products are packaged for a particular target group. Second, an analysis of existing packaging and those of competitors is generally undertaken. This involves asking consumers to rate attributes of existing packs with those of competitors. Third, clear brand positioning objectives are established to communicate the brand's "personality" and this includes looking at broader advertising and sales promotion plans for the brand. Fourth, identification of the product's attributes needs to occur to help prioritise text and visual elements of the intended communication elements on the pack. Fifth, precisely targeted package design criteria are established, including recognition, image communication, and technical requirements. All of this research and decision making is pulled together to brief the package designer, who may either work within the company or within an advertising agency (for example, Philip Morris has used the Leo Burnett advertising agency).

From this information, a broad range of brand identity and package design explorations are developed, from which a smaller range are selected for further development and consumer feedback. Feedback from consumers generally occurs through focus groups or one-on-one interviews, and this research shapes decision making about the final concepts for further development. Three dimensional mock-ups are generally made of these designs for additional consumer feedback, after which full working models and specifications would be made for the artwork, production, and printing process. New packs may be subjected to a full scale test market, where sufficient quantities of the new packs filled with cigarettes are delivered to retailers, and records are kept of sales of the new packs, with due attention being paid as to whether the new packs impact unfavourably on existing brands owned by the company. This process usually involves a lengthy period of time-several months to a year or more- to observe and monitor the movement of test packs. Documents pertaining to all of these stages of packaging research and design were found in tobacco company websites.

\section{Role of packaging in tobacco marketing}

Tobacco companies have long recognised the importance of packaging in complimenting and extending the imagery created by advertising. As early as the 1950s, some US\$150 000 was spent on packaging research by Philip Morris, ${ }^{23}$ equivalent to around \$1 million in today's terms. To facilitate Marlboro's "repositioning" from a woman's cigarette ("Mild as May") to a man's smoke in the 1950s, "more than 120 different additional superogatory designs were created, rendered and researched. They were tested for eye movement, for associated characteristics, for emotional impact, for every attribute within the power of Vienna to define or invent". ${ }^{24}$ (Here, Vienna is a reference to Freudian psychiatry.)

The influence of packaging is so great as to persist even when smokers are trained and practised in distinguishing between different brands of cigarettes when they are smoked. In 1980, British American Tobacco (BAT) investigated the influence of brand identification and imagery on subjective evaluation of cigarettes. The study exposed a panel of smokers to a control condition where the brand identification was masked and packs were absent, a condition where brand identification markings were visible on the cigarette but packs were absent, or a condition where cigarettes were contained in the pack from which they would normally be taken. The study found "...even with the use of panelists who are trained to be objective in their evaluation of cigarettes, that both brand identification and pack imagery variables have a significant effect on the individual's perception of the sensory attributes of the product." ${ }^{25}$ The concept of "sensation transfer" from the pack to the product, sometimes called the "halo effect" of packaging, is an important phenomenon. As will be later illustrated, it is a critical factor in creating the impression of lower tar cigarettes.

Packaging is also particularly important in promoting the trial of a new cigarette brand and this often occurs at the point of purchase. As explained in a report commissioned by the Liggett and Myers company: "the primary job of the package is to create a desire to purchase and try. To do this, it must look new and different enough to attract the attention of the consumer. Repeat sales will depend mostly on acceptance of the product, although packaging features such as convenience in use and protection certainly play an important role." ${ }^{26}$

As advertising restrictions increase, the cigarette pack becomes ever more important as a means of communicating brand imagery. Where usual advertising channels are available, packaging works in concert with advertising imagery, complimenting the images generated by print or electronic advertising. However, in the face of advertising bans, documents show that tobacco companies realised that the pack would have to assume a much more prominent role in communicating differences between cigarettes and, particularly, brand imagery. In countries where advertising bans are comprehensive to the extent that point of purchase offers the only possibility for advertising, packaging is vital.

For example, in 1980, the senior vice president of marketing at BAT noted the dire importance of packaging where comprehensive bans on advertising were in place, as in Finland and Singapore, stating his belief that packaging would ultimately become the strongest communication device. "In a future where increasingly the product may have to sell itself through the pack, a fuller understanding of the way in which perception of such packs affects perception of their contents is desirable."25

In a speech given as part a Philip Morris international marketing meeting in Tampa, Florida in 1990, participants heard from the product innovation group in the European region that, since restrictions on conventional advertising media were forecast to increase, "our new product development program must therefore focus on those areas of opportunity which do not rely on conventional media."27 This included "new types and forms of packaging that can act as a means of communication" and also sponsorship involving "using a cigarette brand to sponsor cultural/social events so that the events together with the brand packaging become the means of communications". The speaker went on to describe a proposed oval pack, which "projects a distinctive young masculine appearance" where concept study testing showed it to be "new, original, sensual, and striking. Test concluded: pack has tremendous appeal among young smokers." A booklet pack and a pack shaped like a cigarette lighter were also featured. "As a conclusion, I think we have demonstrated that new cigarette products and brands have a future, even though our enemies want us to stop innovating the market. We shall overcome.",27

In a highly competitive market, it is important that consumers can identify their preferred brand from among the range of brands that are available. As one BAT document explains, this is especially the case at the point of purchase. "..it is felt that given the consequences of a total ban on advertising, a pack should be designed to give the product visual impact as well as brand imagery ... The pack itself can be designed so that it achieves more visual impact in the point of sale environment than its competitors."28 Thus, cigarette packs that are easy to identify are ideal advertisements in and 
of themselves, and can be designed to achieve optimum salience when arranged on retail shelves.

For some years, companies have been redesigning packs so that brand families are sufficiently similar to indicate membership of the overall parent brand, and different enough to be able to distinguish between the variants. This is well reflected in an American Tobacco Company memo which advised that "An integrated package design can provide for a greater in-store presence. One package or carton color with integrated bull-eye design can better compete as a 'family' in today's cluttered in-store environment."129 In this way, the arrangement of packs at the point of purchase themselves become an advertisement for the brand family.

The design of Philip Morris' Marlboro pack represents one of the most successful and most recognisable designs in cigarette packaging. Pack recognition research used by tobacco companies involved the use of a tachistoscope containing a visual field onto which stimuli such as packs were exposed for precisely measured durations under controlled illuminations. Using this instrument, each pack was presented to the consumer in a series of short regularly spaced exposures starting at subliminal levels and proceeding in submillisecond increments through the stages of partial recognition of information on the pack, to the stage of full recognition. The test then measured the mean recognition time for each pack. ${ }^{28}$ One BAT document describing results of pack testing using this procedure on BAT brands lamented the fact that "the performance of all the packs in the exercise is substantially outstripped by the Marlboro pack which delivers a 3.16 millisecond threshold." This time to recognition was half the time achieved by any of the BAT brands. It goes on to say: "Consistent trends indicate that chevrons have high image prominence but with the tendency for upwards pointing chevrons to draw attention to themselves and downward pointing chevrons to draw attention to that at which they point at [sic].".30

A document from the Philip Morris site in 1970 which summarised the Marlboro packaging story explained how pack recognition research was conducted by using hidden cameras on unsuspecting consumers in retail stores. "As a prospective customer entered this area, he broke the photoelectric beam immediately setting in motion the concealed camera which recorded the movement of his eyes and the final selection he made. From the thousands of films, the designers, color experts and advertising men were able to determine which package, which design and what combination of colors had the most appeal and "purchase incentivepick me up" for the consumer." ${ }^{\prime 31}$

The importance of pack graphics in recognisability is further underlined in a Leo Burnett office memo presenting the results of a pack recognition study, the prime purpose of which was to determine whether Philip Morris' Merit pack with its logo had sufficient recognition to stand alone, to the extent that the name "Merit" was no longer required. Packs which had had the brand name masked were presented one at a time to "a general cross-section of smokers". The study found that "the older, larger share brands gravitate to the top of the list, with Marlboro and Winston leading the charge . . Marlboro Lights was the youngest brand in the top tier, obviously buoyed by the "roof" logo, which continues to attain extraordinary recognition whether in red or gold.".32

Because smokers carry packs around with them, taking them out many times each day to complete the ritual of lighting up, and often leaving them in an exposed and within easy reach location, the pack itself, through its association with brand image, can communicate a lot about the person who smokes. Tobacco companies undertake a considerable amount of assessment before modifying pack designs, since it is so important that smokers feel comfortable carrying the pack around and uninhibited to take it out to light up. In a memo recommending the commencement of exploratory research for the Lucky Strike cigarette line, advice to the vice-president of brand management of the American Tobacco Company was that "focus groups have indicated that the green (Lucky Strike) pack would be well received by young adult males . . . they thought it was eye-catching and a different approach to packaging ... specifically they stated, it would be great to put down on the bar." ${ }^{\prime 33}$

Thus, these documents reveal that packaging plays an important role in creating and reinforcing brand imagery. In the case of advertising restrictions, pack design assumes greater importance in driving brand imagery, and plays a key role in competing for potential consumer attention at the point of purchase.

\section{Pack design effects on perception of cigarette strength and taste}

With concerns about the health risks of smoking being aired in the 1950s, tobacco companies began to introduce filter cigarettes. In the 1960s and 1970s, this concern gained momentum with the publication of the first Surgeon General's report and broadcasting of the first televised anti-smoking advertising, prompting the introduction of cigarettes that were claimed to be lower in tar, or "milder". Research has demonstrated that these "lower tar" cigarettes did not in fact deliver lower tar when smoked, due to vent blocking and compensation through deeper inhalation..$^{34}$ Further, research indicates that the use of terms such as "low tar" and "light" cigarettes were purposefully designed to mislead the consumer into believing that they were smoking a lower tar or safer product. $^{1035}$

Aside from the brand name and descriptors, however, tobacco industry documents show that other aspects of pack design were purposefully used to communicate and reinforce the impression of lower tar or milder cigarettes. A wide range of colours and design configurations were market tested with consumers to determine designs that most led consumers to perceive that the cigarettes in the pack were "mild" or lower in strength. A common thread through all of this research has tobacco companies grappling with the difficulty of preserving taste satisfaction, while simultaneously reducing perceptions of cigarette strength.

Companies discovered that lighter colours on the pack appeared to promote perceptions of lower cigarette strength. For example, throughout 1979 and 1980, RJ Reynolds was testing packaging modifications to its Camel Filter brand, in an attempt to determine a design which was "able to reduce the communication of product strength among potential users of the brand while maintaining current satisfaction, taste and image perceptions". ${ }^{36}$ The tests led to packaging changes which were summarised as follows: "refinements in the package consist mainly of increasing the amount of white space on the pack and lightening the brown color tones. While other changes were made these were essential to give the revised package the appearance of reduced strength." ${ }^{\prime 36}$ Also, the colour of the word "Camel" on the pack was made a lighter brown.

The colour blue is often associated with low tar cigarettes. For example, results of a mall intercept survey of smokers' responses to new packaging for Marlboro Ultra Lights found that both Marlboro and other brand smokers "felt that both the red and blue Marlboro Ultra Lights packs were lower in tar and milder in taste than the majority of other brands, although the blue pack was reported to be somewhat lower in tar and milder in taste than the red pack" ${ }^{37}$ In a test later that year, Philip Morris marketing research department compared smokers' responses to cigarettes packaged in a blue and a red pack. Despite the cigarettes being identical in composition, smokers appraised the cigarettes in the blue pack as "too mild", "not easy drawing", and "burn too fast". Others felt the cigarettes in the red pack were "too strong" and "harsher". 
This example is one of hundreds of routinely used pack tests, which employ the principle of "sensation transfer" from pack to product to influence consumer's perceptions of the smoking experience of cigarettes. "Lower delivery products tend to be featured in blue packs. Indeed, as one moves down the delivery sector then the closer to white a pack tends to become. This is because white is generally held to convey a clean healthy association." ${ }^{27}$

Soft packs were understood by tobacco companies to create the perception of stronger cigarettes than hard packs, as evidenced in this Philip Morris memo: "The absolute ratings of both cigarettes, in terms of mildness, may be higher (that is, the cigarettes may be perceived as less intense) when the cigarettes are presented in the box.."39

Menthol cigarettes were first marketed as being good for a cold or flu, as health concerns grew over cigarette smoking. Menthol originates from the peppermint plant and packaging reflected concepts of freshness and mint flavour. Green colours in menthol packaging were predominantly used to influence expectations of menthol taste ${ }^{40-43}$ As one of the first brands to promote menthol, RJ Reynolds' Salem brand was promoted as being "as refreshing as all outdoors". ${ }^{44}$

\section{Pack designs for target groups}

Basic marketing principles advocate the use of market segmentation. ${ }^{15}$ Segmentation analysis recognises that potential consumers have diverse needs and wants, and that by carefully identifying and characterising these subgroups, product marketing can be tailored to elicit a more positive consumer response. Documents show that all of the tobacco companies use segmentation analysis as a strategy for assisting with decision making about pack design.

\section{Packaging to appeal to young adults}

Documents repeatedly show that tobacco companies are aware that brand choices are made relatively early in the life of a smoker and that packaging is an important ingredient in positioning brands to be attractive to youth. A Liggett and Myers document, for example, stated: "16-21-the formative years; smoking starts and brand preferences are developed."25

Tobacco companies constantly check with consumers to see whether cigarette packaging is perceived as old or outdated. This is especially important, when the age skew of the consumer is young, where fashions come and go so quickly. A market research presentation for Philip Morris notes the need for 'new' packaging to maintain appeal for young smokers. “Once exposed to 'innovative', especially young adults see their current packaging as dated and boring" ${ }^{46}$ This document goes on to say that the value of "new" is that it "draws attention (jealousy) from others" and that "especially young adult consumers are ready for change in packaging". ${ }^{46}$ Another report for Philip Morris mused that ". . .we hear from consumers that RJR's foil wrap provides an example of something new, shiny, a little more contemporary to look at than other brands provide may be enough to tempt new smokers to try (sic)."'47

This concern with the importance of novelty for the young surfaces again in a Philip Morris report from its Research Center in Richmond, Virginia. The Center conducted a series of nine packaging preference studies up to June 1995 whereby smokers ranked a variety of new pack designs, with the final study recommending that "a plastic pack has particular appeal among the young, fitting their lifestyle of sports, outdoor activities and being 'on the go'. Based on this information, we recommend that a plastic pack be pursued in future testing." ${ }^{\prime 8}$

In the 1970s young smokers were targeted with Lorillard's Zack cigarettes in a denim package. In a Lorillard memo proposing tracking of consumer attitudes towards Zack cigarettes in August 1974, Walter Lancaster of Lorillard explained: "This new lo-fi entry is targeted at young smokers under 30 years old ...Marlboro smokers are the brands prime target because of the young age skew of the brand ... Zack's strength in appealing to young adults is its unusual name, denim pack and graphic entity." ${ }^{\prime 9}$ In focus group discussions the following year for Lorillard, a marketing executive from the Will Graham Company reporting back from focus group discussions concluded that "Zack is a perceived as a brand for open-minded free thinking people who are young in spirit, if not in fact". This point was reinforced by an illustrating that "one teacher said Zack seems to be replacing Marlboro as the pack her students carry" ${ }^{50}$

A 1973 memo which proposed a possible "Turk" blend for Camel Filter brand designed to compete with Marlboro suggested that the company "continue to explore and evaluate the need for a dramatically redesigned package that would significantly increase the brand's young adult image/ appeal". ${ }^{51}$ In market testing of alternative pack designs for Camel Lights, a market research report for the RJ Reynolds company asserted that "the alternative packs seem to 'fit' better with present advertising and this advertising was, in turn, very consistent with 'role model' and imagery desires of the younger smokers." ${ }^{52}$

A 1979 memo from Edward Ricci at MCA Graham Advertising to Tom Mau of Lorillard discussed the positioning of the Newport box package in the low tar market, explaining that "the Box is on target today in terms of drawing LT (low tar) prone Newport smokers and, more so long term, for attracting a greater percentage of young adult new entrants"..$^{33}$ Some years later, as the Newport brand was increasing its market share, Philip Morris drew the same conclusion about the appeal of box packaging for younger low tar consumers as a strategy to win back young smokers. "A brand to compete with Newport targeted toward young smokers may have stronger impact on this market if packed in a box"..$^{54}$

A qualitative investigation of Old Gold Filters by Unisearch for Lorillard in 1978, "reaction to the prototype package appeared to be the following: class, expensive, elegant" but then reflected "Biggest problem: Is this a young adult package?". ${ }^{55}$

\section{Packaging for women}

Packaging to appeal to women has been the subject of careful research. Cigarettes for women are often packaged in slim, long packs, often with pastel or toned down colours, to meet perceived desires to appear feminine and sophisticated. "Some women admit they buy Virginia Slims, Benson and Hedges etc. when they go out at night, to complement a desire to look more feminine and stylish". ${ }^{47}$ This report went on to say: "Throughout all our packaging qualitative research, we continue to validate that women are particularly involved with the aesthetics of packaging ... we sense that women are a primary target for our innovative packaging task, and that more fashionable feminine packaging can enhance the relevance of some of our brands." ${ }^{47}$

In 1992, Philip Morris was exploring different ideas for packaging of Virginia Slims Kings. In describing these plans, a Philip Morris memo indicated that "recent qualitative research indicates that female smokers, particularly young adults, show great interest in new packaging designs. In fact, this group has indicated a desire for packaging revolution, rather than evolution" ${ }^{56}$ In a two day workshop, Leo Burnett's Idea Lab generated more than 60 new packaging ideas for Philip Morris, including-believe it or not-headbands, belts, and shoe attachments containing cigarettes. Ultimately the company conducted further research on three of these-a "Booklet" pack (opening like a booklet with three packs that could be separated) a "ComPack" (designed to replicate a women's powder compact case), and an Oval Pack (a soft pack that could be squeezed at each end to access cigarettes). 


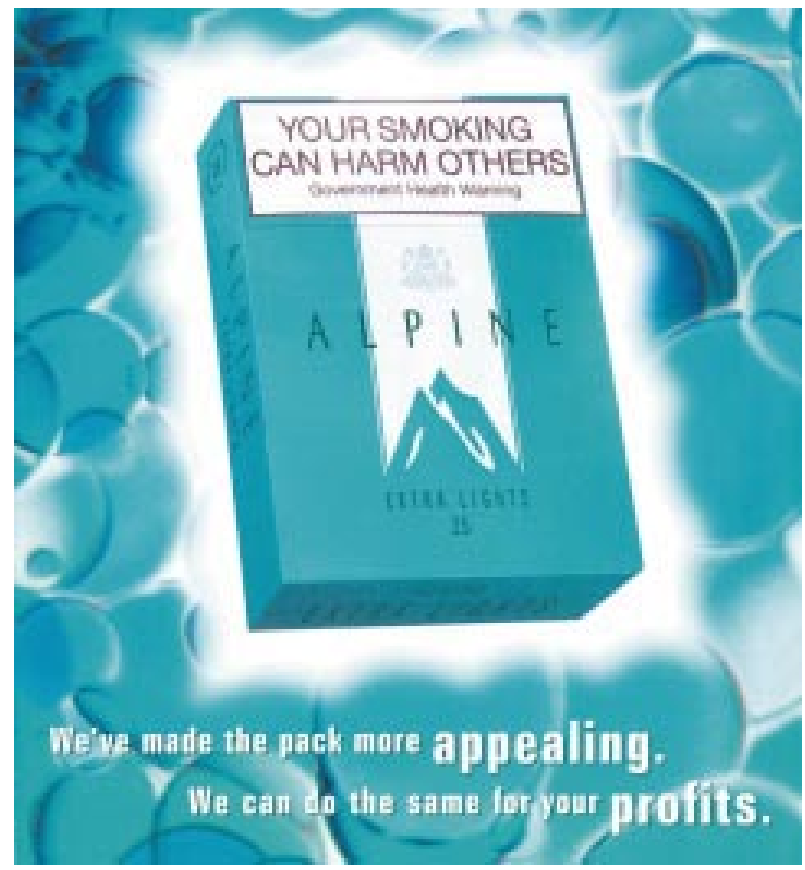

Figure 1 Philip Morris promotes its new Alpine pack design to tobacco retailers, citing its more appealing look that is "assured to drive Alpine sales". Crows Nest, New South Wales, Australian Retail Tobacconist, July 1999, p 7. Thanks to Jane Martin from Quit Victoria for locating this advertisement.

Philip Morris also deliberated at length about revising the Alpine pack, which is a predominantly female brand. In March, 1994, Colmar Brunton conducted focus groups in Melbourne Australia for Philip Morris in order to "revitalise and strengthen the quality appeal of the Alpine brand in the 90 's". The company's brief was a to explore what kind of communication and packaging concepts would most appeal to women. It wrestled with the issue of "how to grab her attention amid the clutter?". ${ }^{57}$ Ultimately, the company was very pleased with its new design, as shown in fig 1.

In a 1961 report on packaging conducted by the Opinion Research Corporation for Philip Morris, the researchers concluded that "there seems to be some evidence that packaging preference is sex-linked, with the hard pack identified as best for women . . the cleanliness of the pack is its greatest attraction for the female smoker" ${ }^{58}$

\section{DISCUSSION}

It is well known that the tobacco industry is highly flexible and responsive in accommodating restrictions to its ability to advertise and promote cigarettes. Previous research has shown that the industry is able to compensate for its inability to advertise in one medium by transferring advertising dollars to other marketing activities. ${ }^{59-61}$ A recent analysis of data on 22 OECD (Organization for Economic Cooperation and Development) countries from 1970 to 1992 concluded that comprehensive bans on advertising/promotion significantly reduce smoking, while limited bans have little or no effect, because of the potential for shifting resources from banned activities to other marketing efforts. ${ }^{62}$ Given the progress made in many countries with tobacco advertising restrictions, cigarette packaging is becoming more important as a component of tobacco marketing. The pack, and its associated point of purchase display, is increasingly becoming a vital avenue for promoting brand imagery and advertising. Research using observational methodology in the USA, for example, has begun to empirically demonstrate that point of purchase marketing strategies are far from a randomly occurring phenomenon, but

\section{What this paper adds}

Limited research has been conducted to date on how cigarette packaging might promote cigarette use or influence brand choice. A search of previously secret tobacco company documents showed that cigarette pack design is an important vehicle for communicating brand image, especially when conventional advertising is restricted. Documents show that careful packaging development leads smokers to perceive their cigarettes may be "safer", suggesting that regulation of packaging is required.

are part of a sophisticated marketing strategy designed to offset the potential beneficial effect of tax increases and tobacco control programmes and policies on tobacco consumption. ${ }^{63-65}$

Tobacco trade and advertising magazine commentaries confirm these empirical findings. As Marc Cohen from Goldman Sachs commented: "anything that a [cigarette] company can do to stand out behind the counter is important, due to big tobacco's agreement with the states that limits advertising." ${ }^{\prime \prime 6}$ The forecast for packaging, according to an April 2001 interview in a tobacco industry journal, is for even greater innovation. "Good cigarette packaging offers an additional dimension that goes beyond the mere wrapping of the product and also beyond the simple consumption of cigarettes-some kind of added value. However, I think that with regard to looming restrictions, the strategy should be completely different: there should be an image transfer for cigarette consumption as such, similar to the image change that was achieved for cigars some years ago ...Packs with a valuable appearance may contribute to this image shift." ${ }^{67}$

These documents indicate that tobacco companies view packaging as an important element in cigarette marketing and have conducted an enormous amount of consumer testing and research on all elements of pack design in order to be sure about the imagery created and reinforced by each cigarette pack. Thus, tobacco companies cannot reasonably claim that they are unaware of consumer perceptions associated with particular packaging features, or that these were unintentional. If packs are effectively acting as advertisements for cigarettes, if their design characteristics make them more attractive to teenage smokers, communicate information about cigarettes that may be misleading (such as implying they are less strong or milder in some way), or minimise the salience of health warnings and contents information, ${ }^{12}{ }^{17}$ then pack design ought to be subject to regulation.

Comprehensive bans on tobacco advertising therefore need to include some consideration of how pack design contributes to the size and salience of point of purchase displays, as suggested by "best practice" point of purchase regulation in Tasmania, Australia. ${ }^{68}$ The Australian experience has shown that where traditional advertising is banned at the point of sale, cigarette packs themselves can be used to make "pyramids, mechanical windmills, entire walls of display stock, designs and patterns on walls, ceilings, floors and anything else a creative advertising agency can dream up" ${ }^{68}$ A comprehensive ban on advertising would mean that cigarettes need to be available only from under the counter, rather than being on display. On the other hand, the unappealing images now used on cigarette packs in Canada to warn consumers of health risks ${ }^{20}$ effectively represent a form of anti-smoking advertising and may lessen the need to withdraw cigarette packs from plain view in retail outlets.

Given this trend, regulation of cigarette packaging should be considered. One obvious policy option would be to require all brands to be packaged in a generic package. Without brand imagery, packs simply become functional containers for cigarettes, rather than a medium for advertising. Reports from Canada and Australia have commented upon how generic 
packaging, which removes brand logos from packs, increases the prominence of health warnings and may increase the believability of health warnings. ${ }^{12}{ }^{17}$ It is also important that consumers not be still further misled into thinking that the cigarettes in the pack are in some way "safer" than others. There may be a case to be made for requiring tobacco companies to demonstrate that cigarettes that deliver the same amounts of tar and nicotine when smoked ought to be packaged similarly. These kinds of issues are raised for regulatory consideration in a briefing paper released by the Framework Convention Alliance as part of the Framework Convention on Tobacco Control. ${ }^{69}$ Public health research on adolescent's pack recognition, and ratings of pack attractiveness to youth should be conducted to assist policy makers to deliberate further on these policy options. Regulatory attention also needs to be directed toward banning the use of easily recognisable, pack derived brand logos without brand names, as has been used in sponsorships, including Formula 1 Grand Prix.

There have been some successful efforts by public health authorities to alert consumers to the fact that so-called "light" and "mild" cigarettes neither deliver lower tar when smoked, nor confer reduced health risks. ${ }^{70} 71$ These kinds of educational initiatives might also point out how tobacco companies carefully design packs to give the appearance of cigarettes lower in strength, through using the sensation transfer phenomenon as a routine part of their product development research. Youth oriented education and advocacy approaches that have sought to publicise tobacco industry marketing approaches might usefully focus upon the way in which tobacco companies use packaging to entice young consumers to their brand.

This paper has focused upon particular aspects of pack design that contribute to brand imagery. However, there are other aspects of packaging that deserve future research. These include developing an understanding as to why cigarettes are packaged in different pack and carton sizes; exploring how price and packaging work in concert to drive brand selection, especially among low income consumers; studying the methods and results of tobacco company research designed to tailor packaging to appeal to potential consumers of different racial and ethnic groups; investigating whether any of the technical aspects of packaging, such as the substances and colourings added to the packaging material itself, might be harmful; and understanding how tobacco companies have worked to obscure required health warnings or contents labelling. Further research on all of these issues is warranted and would provide important evidence to guide regulatory initiatives.

\section{ACKNOWLEDGMENTS}

The research described in this paper was supported by grants from the National Cancer Institute CA77021-03, CA87696-01, and by Core Grant CAl6056-26. The authors thank Richard Pollay for helpful comments on a draft of this paper.

\section{Authors' affiliations}

M Wakefield, Centre for Behavioural Research in Cancer, Anti-Cancer Council of Victoria, Victoria, Australia

C Morley, J K Horan, K M Cummings, Department of Cancer Prevention, Epidemiology and Biostatistics, Roswell Park Cancer Institute, Buffalo, New York, USA

\section{REFERENCES}

Armstrong G, Kotler P. Marketing: an introduction. New Jersey: Prentice Hall, 2000

2 Solomon M, Bamossy G, Askegaard S. Consumer behaviour: a European perspective. New Jersey: Prentice Hall, 1999.

3 Shimp T. Advertising, promotion and supplemental aspects of integrated marketing communications, 5 ed. Dryden Press, 2000

4 McCarthy EJ. Basic marketing: a managerial approach. Homewood, Illinois: Irwin, 1960.

5 Slade J. The pack as an advertisement. Tobacco Control 1997;6: 169-70.
6 Koten J. Tobacco marketer's success formula: make cigarettes in smoker's own image. Wall Street Journal 1980; February 29: p 22.

7 Pollay RW. Is outdoor advertising FAIR to children? Expert opinion in FAIR vs City of Chicago (97C76 19) TIPS Working Paper 98.1. History of Advertising Archives, Faculty of Commerce, University of British Columbia, April 1998.

8 Cummings KM, Hyland A, Lewit E, Shopland D. Discrepancies in cigarette brand sales and adult market share: are new teen smokers filling the gap? Tobacco Control 1997;6(suppl):S38-43.

9 Difranza JR, Eddy JJ, Brown LF, et al. Tobacco acquisition and cigarette brand selection among youth. Tobacco Control 1994:3:334-8.

10 Pollay RW. Targeting youth and concerned smokers: evidence from Canadian tobacco industry documents. Tobacco Control 2000;9: 136-47.

11 Thiboudeau M, Martin J. Smoke gets in your eyes: branding and cigarette design in cigarette packaging. New York: Abbeville Press, 2000.

12 Centre for Behavioural Research in Cancer. Health warnings and product labelling on tobacco products. Melbourne: Anti-Cancer Council of Victoria, 1992

13 Borland R. Tobacco health warnings and smoking-related beliefs and behaviours. Addiction 1997:92:1427-35.

14 Borland R, Hill D. The path to Australia's tobacco health warnings. Addiction 1997;92:1151-7.

15 Environics Research Group Limited. Health warnings testing: final report. Prepared for Health Canada. Ottawa, June 24, 1999

16 Environics Research Group Limited. Testing new health warning messages for cigarette packages: a summary of three phases of focus group research. Final Report prepared for Health Canada. May, 2000.

17 Centre for Health Promotion. Effects of plain packaging on the image of tobacco products among youth. Toronto, Canada: University of Toronto, November 30, 1993.

18 Beede $\mathbf{P}$, Lawson R. Brand image attraction: the promotional impact of cigarette packaging. NZ Family Physician 1991;18:175-7.

19 Beede P, Lawson R. The effect of plain packages on the perception of cigarette health warnings. Public Health 1992;106:315-22.

20 Mahood G. Warnings that tell the truth: breaking new ground in Canada. Tobacco Control 1999;8:356-62.

21 Anon. Marlboro advertising brief for Leo Burnett Australia, 23 July, 1984. Bates 2023265680-2023265683. URL http:// www.pmdocs.com/getallimg.asp? $\mathrm{if}=$ avpid $\& \& D O C I D=2023265680 /$ 5683

22 Myers HM, Lubliner M. The marketer's guide to successful package design. Chicago, Illinois: NTC Business Books, 1998.

23 Cheskin L. Philip Morris launches an expansion program. Secrets of Marketing Success. New York: Trident Press, 1967.

24 Lyon DG. Off Madison Avenue. New York: GP Putnam, 1966:65-6.

25 Ferris $\mathbf{R}$. The influence of brand identification and imagery on subjective evaluation of cigarettes. British-American Tobacco Co. Ltd Group, July 18, 1980. Access date: 13 September 2001. Bates No. 400235714-400235752. URL: http://outside.cdc.gov:8080/BASIS/ ncctld/web/mnimages/EDW?W=DETAILSID $=26302$

26 Miller A. Arthur D Little Inc. Development of Cigarette Packaging, Liggett and Myers, \#194, p, 17. October 14, 1963. Originally acquired from http://www.gate.net/ jcannon/liggett/\#top (website no longer active). Presently available in the Roswell Park Youth and Marketing Collection linked through http://roswell.tobaccodocuments.org, document \# 194

27 Philip Morris, Marketing New Products in a Restrictive Environment. June 1990. Access date: September 3, 2001. Bates No. 2044762173-2364. URL: http://www.pmdocs.com/ getallimg. asp? $i f=$ avpid $\times \& D O C I D=2044762173 / 2364$

28 Miller L. Principles of measurement of visual standout in pack design. Report No. RD 2039 Restricted. Group Research \& Development Centre British American Tobacco Co Ltd, May 23, 1986. Bates No. 102699347-102699500

29 Bogie JC. Approval recommendation - Lucky Strike Package Design Exploratory, Memo to RE Smith, January 7, 1991, American Tobacco Company. Bates No. $970530514-970530521$

30 Anon. Product communication in the context of varying degree of ad restrictions, Behavioural Research/Smoker Studies Seminar, Viking Inn, Canada, 1980. Brown \& Williamson, Bates No. 542003674-542003684

31 Anon. The Pack the People Picked. Philip Morris. July, 1970. Access date: September 3, 2001. Bates No. 2501265559-5565. URL: http://www.pmdocs.com/ getallimg.asp? $\mathrm{if}=$ avpid $\& \& D C I D=2501265559 / 5565$

32 Kuhn F. Pack Recognition Research. Philip Morris. December 17, 1987. Access date September 3, 2001 . Bates 2040214382-2040214387. http://www.pmdocs.com/ getallimg.asp? $i f=$ avpidx\&DOCID $=2040214382 / 4387$

33 Bogie C. Approval recommendation - Lucky Strike Package Design Exploratory, Memo to RE Smith, October 23, 1990, American Tobacco Company, Bates No. $970135576-970135580$

34 Kozlowski LT, Pillitteri JL. Compensation for nicotine by smokers of lower-yield cigarettes. In: The FTC cigarette test method for determining tar, nicotine, and carbon monoxide yields of US cigarettes: report of the $\mathrm{NCl}$ expert committee. Bethesda: Maryland: National Cancer Institute, US Department of Health and human Services; 1996:161-72.

35 Pollay RW, Dewhirst T. The dark side of marketing seemingly "Light" cigarettes: successful images and failed fact. Tobacco Control 2002;11 (suppl I):i 1 8-31.

36 Etzel E. Consumer research proposal: Camel Filter revised packaging Test Study. RJ Reynolds. March 2, 1979. Access date: September 17, 
2001. Bates No. 500566627-500566632. URL: http:// www rirtdocs.com/rirtdocs/image viewer dms? DOC RANGE $=500566627+-6632 \& S E A R C H=486 \&$ CAMEFROM=1\&PS= 1

37 Phillip Morris. Marlboro Ultra Light Pack Study: Top-line Results. February 9, 1981. Access date: September 3, 2001. Bates No. 2048718182-8194. URL: http://www.pmdocs.com/ getallimg. asp? $i f=$ avpidx\&DOCID $=2048718182 / 8194$

38 Isaacs J. Identified HTI test of Marlboro Ultra Lights in a blue pack versus Marlboro Ultra Lights in a red pack. Philip Morris. July, 1981. Access date: 17 September 2001. Bates No. 204387079-204387089. URL: http://www.pmdocs.com/ getallimg. asp? $i f=$ avpidx\&DOCID $=2047387079 / 7089$

39 Dennis D. Memo to CP Loh: The effects of soft pack versus box packaging of test cigarettes on consumer perceptions. Philip Morris. August 26, 1982. Access date: September 17, 2001. Bates No.1000409218/9239. URL: http://www.pmdocs.com/ getallimg. asp? $\mathrm{if}=$ avpid $\&$ DOCID $=2051989496$

40 Martin PG. Two pastel green menthol field tests. Philip Morris. September 1973. Access No. September 17, 2001. Bates No. 1000352340-1000354495. URL: http://www.pmdocs.com/ getallimg.asp? $i f=a v p i d x \& D O C I D=2062951967 / 2115$

41 Howes R. National Test Ranking: Saratoga Menthol, More Menthol, Saratoga Menthol with Green Paper. Philip Morris. July 1976. Access Date: September 3, 2001. Bates No. 1000361781-1794. URL: http://www.pmdocs.com/ getallimg.asp? $i f=a v p i d x \& D O C I D=1000361781 / 1794$

42 Greene R. Green (chlorophyll coated) wrapper menthol cigarettes. Philip Morris. April 4, 1978. Access date: September 17, 2001. Bates No. 1000368490/8507 URL: http://www.pmdocs.com/ getallimg.asp? $i f=$ avpid $\&$ DOCID $=1000368490 / 8507$

43 Martin P. Two national POL mailout tests: Philip Morris. March 27, 1973. Access date: September 17, 2001. Bates 1000724909-1000724911. http://www.pmdocs.com/ getallimg.asp? $i f=$ avpid $\& D O C I D=1000724909 / 4911$

44 Freeservers, Inc. Growth of menthol cigarettes. Access date: October 18, 2001. URL: http://goodhealth.freeservers.com/ mentholCigGrowth.htm

45 Belch GE, Belch MA. Advertising and promotion: an integrated marketing communications perspective. Boston: Irwin McGraw-Hill, 1998

46 Anon. Opportunities in packaging innovation. Philip Morris. March 1992 Access date: September 17, 2001. Bates No.2023162454-2023 162473. URL: http://www.pmdocs.com/ getallimg.asp? if=avpidx\&DOCID=2048976191/6208

47 Philip Morris, Marketing perceptions [Untitled research report on marketing perceptions]. April 1992. Access date: September 3, 2001 Bates No. 2060037883-7936. URL: http://www.pmdocs.com/ getallimg. asp? $\mathrm{if}=$ avpid $\& \& D O C I D=2051989072 / 9123$

48 Jones, J. Results of the 1985 alternate packaging study. Philip Morris. November 1, 1985. Access date: September 3, 2001. Bates No. 2051989072-9325. URL: http://www.pmdocs.com/ getallimg.asp? $i f=$ avpidx\&DOCID $=2051989072 / 9123$

49 Lancaster, W. Zack Tracking/attitude research request. Lorillard. August 15, 1974. Access date: September 3, 2001. Bates No: 91260420. URL: http://www.lorillarddocs.com/ getallimg. asp? if=avlidx\&DOCID=91260420

50 Don, Will Graham Company. Confidential: Memo to Will, Frank, Linda, Bill, Norman, Bob and Pat]. Lorrillard. February 3, 1975. Access date: September 3, 2001. Bates No. 91257214-7216. URL: http://www.lorillarddocs.com/ getallimg. asp? $i f=$ avlidx\&DOCID=91257214/72 16

51 Standen C. Product and packaging: recommended next steps: "Turk" test market. RJ Reynolds. May 25, 1973. Access date: 18 September
2001. Bates No. 500725191. URL: http://www.rirtdocs.com/rirtdocs/ ImageDownloader.dms?DOC_RANGE $=500354766+-4766 \&$ PDF =true

52 Shostak JR. Topline: Camel Lights new pack focus groups (RIO) October 17, 1980, Bates 500684272-500684288

53 Ricci E. Newport Lights box basis for interest. Lorillard Tobacco Company. January 5, 1979. Access date: September 17, 2001. Bates No. 85087247-850872454. URL: http://www.lorillarddocs.com/ getallimg.asp? $i f=a v l i d x \& D O C I D=85087247 / 7254$

54 Jones J, Johnston M. Packaging preference among smokers of $85 \mathrm{~mm}$ menthol brands. Philip Morris. July 26, 1985. Access date: Bates No. 2051989326-9363. URL: http://www.pmdocs.com/ getallimg. asp? $\mathrm{if}=$ avpidx\&DOCID $=2051989326 / 9363$

55 Unisearch. A qualitative investigation of Old Gold Filters, December 1978, Bates 85395177-85395183.

56 Cohen C. Virginia Slims King Size packaging/plans. Philip Morris. Apri 23, 1992. Access date: September 3, 2001. Bates No. 2054865625. 5628. URL: http://www.pmdocs.com/ getallimg. asp? if=avpidx\&DOCID $=2054865625$

57 Colmar Brunton Research. Qualitative Research Alpine Creative Presentation. Philip Morris, March 1994. Access date: September 3 2001. Bates No. 2504102678-2701. URL: http://www.pmdocs.com/ getallimg.asp? $i f=$ avpidx\&DOCID $=2504102678 / 2701$

58 Opinion Research Corporation. Smoking behavior and smoker motivation: their Implications for Packaging. Philip Morris. November 1961. Access date: September 17, 2001. Bates No. 100811426-1001811544. URL: http://www.pmdocs.com/ getallimg.asp? $\mathrm{if}=$ avpid $\&$ DOCID $=1001811426 / 1544$

59 US Department of Health and Human Services. Reducing the health consequences of smoking: 25 years of progress. A report of the Surgeon General, 1989. Rockville, Maryland: Public Health Service, Centers for Disease Control, Office on Smoking and Health, 1989. (DHHS Publication No (CDC) 89-8411.)

60 Saffer $\mathrm{H}$. Economic issues in cigarette and alcohol advertising. J Drug Issues 1998;28:781-93.

61 Hastings GB, MacFadyen L. A day in the life of an advertising man: review of internal documents from the UK tobacco industry's principal advertising agencies. BM 2000;321:366-71.

62 Saffer H, Chaloupka F. The effect of tobacco advertising on tobacco consumption. Journal of Health Economics 2000;19:1117-37.

63 Chaloupka F, Slater S, Wakefield M. USA: price cuts and point of sale ads follow tax rise. Tobacco Control 1999;8:242-6.

64 Slater S, Chaloupka F, Wakefield M. State variation in retail promotions and advertising for Marlboro cigarettes. Tobacco Control 2001;10:337-9.

65 Wakefield M, Terry Y, Chaloupka F, et al. Tobacco industry marketing at the point-of-purchase after the 1998 MSA billboard advertising ban. Am J Public Health (in press).

66 Beardi C. RJR extends Winston line. Advertising Age May 21, 2001.

67 Rossel S. Special cigarette packaging: new shapes could set a benchmark. Interview between Stephanie Rossel and Professor Peter Zac. Tobacco Journal International 2001, April 4. www.tobaccojournal.com

68 Barnsley K, Jacobs M. Tobacco advertising and display of tobacco products at point of sale: Tasmania, Australia. Tobacco Control 2000;9:230-2.

69 Framework Convention Alliance. Packaging and labelling in the FCTC: Recommended text. Briefing papers INB3. URL: http://www.fctc.org/INB3brief_label .pdf

70 Kozlowski LT, Yost B, Stine MM, et al. Massachusetts' advertising against light cigarettes appears to change beliefs and behavior. Am J Prev Med 2000·18:339-42.

71 Kozlowski LT, Palmer R, Stine MM, et al. Persistent effects of a message counter-marketing light cigarettes: results of a randomized controlled trial. Addict Behav 2001;26:447-52. 